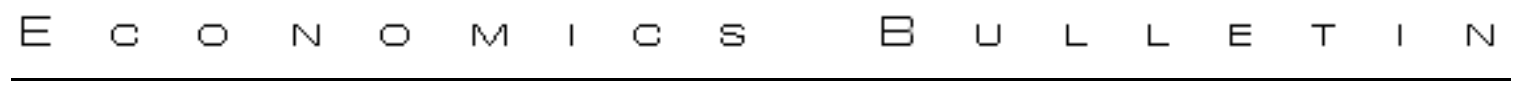

\title{
The lead of output over inflation in sticky price models
}

\author{
Michael Kiley \\ Federal Reserve Board and $O E C D$
}

\begin{abstract}
Output growth is negatively correlated with inflation, detrended output is positively correlated with inflation, and output growth and detrended output lead inflation. I explore the consistency of these correlations with three models of price adjustment: the partial adjustment model, a staggered price setting model, and the P-bar model. The ratio of the variance of supply to demand shocks necessary to match the pattern of output-inflation correlations can be ranked across the three models; the P-Bar model requires the lowest ratio, and the partial adjustment model requires the highest ratio. The imperfect information aspects of staggered price setting and the P-bar model drive some of the output/inflation nexus, highlighting a link with the tradition from Hume to Lucas to recent work by Mankiw and Reis.
\end{abstract}

\footnotetext{
I would like to thank Michael Binder, Guillermo Calvo, Allan Drazen, Paul Evans, and especially John Haltiwanger for helpful discussions and comments on this topic. Of course, all remaining errors are mine. This work was completed at the University of Maryland and the Federal Reserve Board. The views expressed herein are the authors alone, and do not reflect the opinion of the Federal Reserve Board or its staff.

Citation: Kiley, Michael, (2002) "The lead of output over inflation in sticky price models." Economics Bulletin, Vol. 5, No. 5 pp. 1-7

Submitted: May 30, 2002. Accepted: August 28, 2002.

URL: http://www.economicsbulletin.com/2002/volume5/EB-02E00004A.pdf
} 


\section{Introduction}

This paper explores the consistency of sticky price and/or imperfect information models of price adjustment with the following stylized facts regarding inflation and output for the major North American and European economies (documented in section 2 below): 1. Inflation and output growth are negatively correlated; 2 . Inflation and detrended output (HP-filtered) are positively correlated; 3 . Output leads inflation, in the sense that the correlations of inflation with past output growth or detrended output are larger than the correlations of inflation with future output. Several different sticky price models are considered, revealing that the model utilized can strongly alter conclusions regarding the importance of supply and demand shocks for the comovement of inflation and output.

While much recent research has emphasized the contemporaneous correlations between inflation and various measures of detrended output, I also emphasize the strong lead of output over inflation experienced in the major North American and European economies (i.e., the phase shift between output and inflation). While the leading relationship of output to inflation is well documented, it has been underemphasized in the evaluation of models with slow price adjustment. Evaluation of several popular models reveals that the most heavily exploited model of nominal price rigidity in aggregate macro models, the partial adjustment model, is incapable of matching the lead of output over inflation and the sign of the contemporaneous inflation-output growth correlation when only demand shocks are considered. The partial adjustment model also requires a larger ratio of the variance of supply to the variance of demand shocks to match the sign and phase shift which characterize the patterns of output-inflation correlations than is required by the other models of price adjustment considered, suggesting that the recent burst of research exploiting the partial adjustment model of price adjustment will find a larger role for supply shocks than would be found using other models of sticky prices.

The slow price adjustment models considered are the partial adjustment model of prices developed in Calvo (1983) and Rotemberg $(1982,1987,1996)$, the Taylor staggered price setting model, and the P-bar model (McCallum (1994)). The staggered price setting model and the PBar model do generate the lead of output over inflation in response to demand shocks, and require a smaller ratio of the variance of supply to the variance of demand shocks to match the output-inflation relationship than the partial adjustment model. Interestingly, these models match the phase shift and place less emphasis on supply shocks because of the information imperfections regarding nominal shocks imbedded in the models, not the nominal price rigidity aspect per se. This emphasis on information problems as an important determinant of the outputinflation relationship follows a long line of thought on monetary economics, from Hume (1752) to Lucas $(1973,1977,1987)$ and Brunner and Meltzer (Brunner and Meltzer (1993)). Mankiw and Reis (2001) have re-emphasized information problems.

\section{Evidence on the Comovement of Prices, Inflation, and Output}

Much recent research has focused on the cyclical behavior of the price level. This research has concluded that the price level is countercyclical, i.e., when output lies above trend, prices lie below trend (Cooley and Ohanian (1991), Chadha and Prasad (1994), Judd and Trehan (1995), Rotemberg (1996), and den Haan (2000)). In contrast, inflation appears to be procyclical (Chadha and Prasad (1994)). Since non-stationarity in the aggregate demand (or "money") 
process results in a non-stationary price level but stationary output in all of the models considered below (i.e., "long-run monetary neutrality"), I focus on the correlations between inflation and various measures of detrended output. This focus on the output-inflation relationship is consistent with the long-standing focus on "Phillips curve" type models.

Table 1 presents the correlation between the growth rate of output (GDP) and inflation in the major North American and European economies since 1960. While the statistical significance of the correlations varies across countries, two patterns emerge. In every case, the contemporaneous correlation is negative (or extremely close to zero). There is also a clear pattern to the lead-lag relationship between inflation and output growth; in every country, inflation is more strongly positively correlated with lagged output than with future output (i.e., $\left.\rho\left(\Delta \mathrm{p}_{\mathrm{t}}, \Delta \mathrm{y}_{\mathrm{t}-\mathrm{i}}\right)>\rho\left(\Delta \mathrm{p}_{\mathrm{t}}, \Delta \mathrm{y}_{\mathrm{t}+\mathrm{i}}\right)\right)$.

Table 2 presents the correlation between detrended (HP-filtered) output at various lags and leads, and inflation. The HP-filtered output series is examined because it focuses on business cycle frequencies. Again, two patterns emerge. First, detrended output and inflation are positively correlated. Second, in every country, inflation is more strongly positively correlated with lagged output than with future output (i.e., $\left.\rho\left(\Delta \mathrm{p}_{t}, \mathrm{y}_{\mathrm{t}-\mathrm{i}}\right)>\rho\left(\Delta \mathrm{p}_{\mathrm{t}}, \mathrm{y}_{\mathrm{t}+\mathrm{i}}\right)\right)$. There is a pronounced phase shift between output and inflation, in the sense that inflation is more strongly correlated with lagged output than with contemporaneous or future values of output. These results have been underemphasized in the evaluation of models of price adjustment (a notable exception is Taylor (1987)), which has focused exclusively on contemporaneous correlations. For example, Chadha and Prasad (1994) report a phase shift, but do not discuss the phase shift, instead emphasizing the procyclical inflation rate. In fact, of the papers mentioned in the section below on the partial adjustment model, only Yun (1996) reports the implications of his model for the phase shift between output and inflation. This lead of output over inflation is a robust stylized fact of business cycles.

\section{Three Sticky Price Models}

Each of the models considered herein will employ very simple aggregate demand determination and driving processes for aggregate supply and demand shocks, in order to focus on the differences in the endogenous dynamics implied by different models of price rigidity. Aggregate demand is given by

$$
\mathrm{y}_{\mathrm{t}}=\mathrm{m}_{\mathrm{t}}-\mathrm{p}_{\mathrm{t}}
$$

where $\mathrm{y}$ is $(\log )$ real output, $\mathrm{m}$ is $(\log )$ money (nominal aggregate demand), and $\mathrm{p}$ is the $(\log )$ price level. This simple specification of aggregate demand (the quantity equation with constant velocity) is used in many models to explore the implications of alternative aggregate supply (i.e., price adjustment) specifications (such as Lucas (1973), Ball, Mankiw and Romer (1988), Blanchard and Fischer (1989), Kimball (1995), and Rotemberg (1996)). Aggregate demand fluctuations are a random walk

$$
\mathrm{m}_{\mathrm{t}}=\mathrm{m}_{\mathrm{t}-1}+\varepsilon_{\mathrm{t}},
$$

where $\varepsilon$ is an i.i.d. shock. Aggregate supply $\left(\mathrm{x}_{\mathrm{t}}\right)$ is also a random walk,

$$
\mathrm{x}_{\mathrm{t}}=\mathrm{x}_{\mathrm{t}-1}+\mathrm{v}_{\mathrm{t}} \text {, }
$$

where $\mathrm{v}$ is an i.i.d. shock. These simple processes insure that the focus is on the endogenous 
dynamics of the sticky price models, rather than the dynamics of the driving processes. ${ }^{1}$

The flexible price equilibrium of this kind of model consists of output at its natural, or aggregate supply determined, rate $\left(\mathrm{y}_{\mathrm{t}}=\mathrm{x}_{\mathrm{t}}\right)$, and prices equal to the flexible price equilibrium value, $p_{t}{ }^{e}=m_{t}-x_{t}$.

\subsection{The Partial Adjustment Model}

The first model of price rigidity examined is the partial adjustment model, and is closely related to Rotemberg (1996). In the partial adjustment model of price adjustment, the (log) aggregate price level evolves according to

$$
\mathrm{p}_{\mathrm{t}}=(1-\pi) \mathrm{p}_{\mathrm{t}-1}+\pi \mathrm{p}_{\mathrm{t}}^{*}
$$

where $0<\pi \leq 1$ is the speed of price adjustment, and $\mathrm{p}_{\mathrm{t}}{ }^{*}$ is the target price. The target price evolves according to

$$
\mathrm{p}_{\mathrm{t}}{ }^{*}=(1-(1-\pi) \rho) \Sigma_{\mathrm{j} \geq 0}((1-\pi) \rho)^{\mathrm{j}} \mathrm{E}_{\mathrm{t}} \mathrm{p}_{\mathrm{t}+\mathrm{j}} \mathrm{e}^{\mathrm{e}},
$$

where the information set at $t$ includes $m_{t}$ and $x_{t}$, and $\rho$ is the subjective discount rate of the price setter(s) under the Calvo (1983) interpretation discussed below.

The partial adjustment model can be given two interpretations. The standard interpretation involves the price setter(s) facing quadratic costs of price adjustment (Rotemberg (1982)). It is well known that quadratic costs of adjustment lead to partial adjustment as in (3.3) and (3.4), where the speed of price adjustment $\pi$ is determined by the parameters of the adjustment cost function. Note that under this first interpretation, the price setters change price in each period, but only adjust their price part of the way towards the equilibrium price. The second interpretation assumes that firms face some constant probability $\pi$ of adjusting price in any given period (Calvo (1983), Rotemberg (1987)); assuming a large number of firms with identical target prices and aggregating individual prices yields (3.3), which states that the price level in period $t$ is determined by the fraction $\pi$ of price setters who change price in period $t$ to $\mathrm{p}_{\mathrm{t}}{ }^{*}$, and the fraction $(1-\pi)$ of price setters whose prices remain unchanged from period $\mathrm{t}-1$ to $\mathrm{t}$. The target price (3.4) simply indicates that firms set current price with an eye on current and future market clearing prices $\left(\mathrm{p}_{\mathrm{t}}^{\mathrm{e}}=\mathrm{m}_{\mathrm{t}}-\mathrm{x}_{\mathrm{t}}\right.$ ) (due to the probability $(1-\pi)^{\mathrm{s}}$ that nominal price has not been adjusted by time s under the constant hazard interpretation of the partial adjustment model). The interesting aspect of this interpretation is that individual firms do not adjust in every period, even partially, yet the aggregate price level evolves according to the partial adjustment mechanism (3.3). This unique aspect of the Calvo constant probability model of price adjustment makes the model extremely tractable (and hence popular in dynamic general equilibrium models such as Hairault and Portier (1993), Kimball (1995), King and Watson (1996), King and Wolman (1996), Rotemberg (1996), Yun (1996), Ireland (1997), Woodford (1998), and Kim (2000)), but also underlies the stark differences between the partial adjustment model and the staggered price setting model. A comparison of this model and staggered price setting along persistence and relative price distributions is contained in Kiley (2002).

\subsection{The P-bar Model}

The model considered in this section is what McCallum (1994) calls the "P-bar" model of price adjustment. This type of slow price adjustment specification was introduced by Grossman

\footnotetext{
${ }^{1}$ Allowing for serial correlation in money growth complicates the analysis without changing the results.
} 
(1974), and has been used by Barro and Grossman (1976), McCallum (1979,1994), Mussa (1981a,1981b,1982), Obstfeld and Rogoff (1984), and Flood and Hodrick (1986), and Chadha and Prasad (1993). ${ }^{2}$ The P-bar model assumes that price adjustment depends upon movements in the equilibrium price level, $\mathrm{p}_{\mathrm{t}}^{\mathrm{e}}$,

$$
p_{t}-p_{t-1}=\pi\left(p_{t-1} e^{e}-p_{t-1}\right)+E_{t-1}\left(p_{t}^{e}-p_{t-1}^{e}\right)
$$

where $0<\pi \leq 1$ is again a "price flexibility" parameter. ${ }^{3}$ (3.5) indicates that in the P-bar model, the price level at $t$ adjusts based on the degree of "disequilibrium" in $t-1$, and adjusts for any expected (as of $\mathrm{t}-1$ ) movements in the equilibrium price. The idea behind this price adjustment equation is that the degree of disequilibrium indicates inflationary pressure in a "sticky" price world $(\pi<1)$, and prices are set before trading in a period so price setters can only adjust at $t$ to the movements in equilibrium prices expected at $\mathrm{t}-1$. This latter aspect of the P-bar model is the sense in which it is an imperfect information model, and is necessary to generate output effects of monetary shocks (i.e., if the expectations operator in (3.5) is dated $\mathrm{t}, \mathrm{p}_{\mathrm{t}}=\mathrm{p}_{\mathrm{t}}^{\mathrm{e}} \forall \mathrm{t}$ ).

\subsection{Staggered Price Setting}

This section presents a version of the Taylor (1980) model of staggered price setting. Taylor's original specification is motivated by wage contracts; herein I consider nominal prices fixed for two periods as in Blanchard and Fischer's (1989) model of staggered price setting. The interest in the Taylor type specification is twofold. First, it is a well known, tractable model of slow price adjustment. More importantly from my perspective is a comparison of the staggered price setting model's ability to match the pattern of correlation between output growth (detrended output) and inflation with the partial adjustment model's implications for the output-inflation relationship because the popularity of the partial adjustment model is due, in part, to its close approximation to the staggered price setting model (Calvo (1983), Blanchard and Fischer (1989)).

In the model, the economy consists of two (equally sized) types of price setters, type 1 and type 2. Both sets of price setters choose a fixed nominal price for two periods, but differ in the period in which they change price, with type 1 price setters changing price in odd periods and type 2 price setters changing price in even periods. Following Blanchard and Fischer (1989), a firm of type $\mathrm{j}$ has desired price in period $\mathrm{t}$ of

$$
\mathrm{p}_{\mathrm{jt}}{ }^{*}=\mathrm{c} \mathrm{p}_{\mathrm{t}}+(1-\mathrm{c}) \mathrm{p}_{\mathrm{t}}^{\mathrm{e}}
$$

which indicates that a firm's desired price depends on the prices charged by all other firms (the price level, p) (with weight $0<\mathrm{c}<1$ ), and on the long run equilibrium price $\left(\mathrm{p}^{\mathrm{e}}\right)$. Approximating the aggregate price level as $p_{t}=(1 / 2)\left(p_{1 t}+p_{2 t}\right)$, and substituting into (3.6) yields type $j$ 's desired price in terms of type $-\mathrm{j}$ 's chosen price,

$$
\mathrm{p}_{\mathrm{jt}}{ }^{*}=\mathrm{bp}_{-\mathrm{jt}}+(1-\mathrm{b}) \mathrm{p}_{\mathrm{t}}{ }^{\mathrm{e}}, \mathrm{b}=\mathrm{c} /(2-\mathrm{c}) \text {. }
$$

In period $t$, only half of price setters change their nominal price, which will hold for two periods.

\footnotetext{
${ }^{2}$ As is clear from the reference list, the contributions of Mussa seem to have made this model of slow price adjustment more popular in the literature on exchange rates and slow price adjustment.

${ }^{3}$ The interpretation of the parameter $\pi$ is specific to each model, but in all the models considered herein $(1-\pi)$ will partially determine the persistence of output fluctuations away from trend. Taylor (1993) and Kiley (2000) have success matching output persistence with the speed of price adjustment in econometric models.
} 
Assuming the price setters at $t$ set their chosen nominal price, $Z_{t}$, equal to the average of their expected desired nominal price (given by (3.7)) over the two periods for which their nominal price is fixed yields the following equation for their chosen nominal price:

$$
\mathrm{Z}_{\mathrm{t}}=(1 / 2)\left(\mathrm{b} \mathrm{Z}_{\mathrm{t}-1}+(1-\mathrm{b}) \mathrm{p}_{\mathrm{t}}^{\mathrm{e}}+\mathrm{E}_{\mathrm{t}}\left[\mathrm{b} \mathrm{Z}_{\mathrm{t}+1}+(1-\mathrm{b}) \mathrm{p}_{\mathrm{t}+1}{ }^{\mathrm{e}}\right]\right) \text {. }
$$

Solving (3.8) yields

$$
Z_{t}=(1-\pi) Z_{t-1}+[(1-\pi)(1-b) / b] \Sigma_{i \geq 0}(1-\pi)^{I} E_{t}\left[p_{t+i}{ }^{e}+p_{t+1+i}{ }^{e}\right],(1-\pi)=\left[1-\left(1-b^{2}\right)^{1 / 2}\right] / b .
$$

The price level is then given by $p_{t}=(1 / 2)\left(Z_{t}+Z_{t-1}\right)$.

\section{Output Growth and Inflation}

The time series behaviors of output growth and inflation are easily determined for each model using (3.1)-(3.9), and are summarized in table 3 (where $\mathrm{L}$ is the lag operator). The output growth implications of the three models ((4.2), (4.4), and (4.6)) are very similar; each model of price adjustment implies that aggregate demand shocks cause an output expansion, followed by negative growth as output returns to its long run, supply determined rate. In this sense, all three models of price adjustment are very similar. Examination of the inflation processes reveals that the implications of the models for price dynamics are very different. In particular, both the P-bar model and the staggered price setting model ((4.4) and (4.6)) imply delayed responses of inflation to aggregate demand shocks (as can be seen by the presence of the lag operator $L$ in the numerator of the lag polynomials), a result which stems from the imperfect information (lagged response to time $t$ information about shocks) aspects of these models. While this point is a clear result of the timing assumptions embedded in the models regarding price changes by firms, and is quite simple, its implications are very important for the literature exploring the dynamic behavior of inflation and output over the business cycle, and have not as yet been acknowledged.

To see the importance of the information imperfections for the output-inflation relationship, the covariances between output growth and inflation implied by the models are reported in table 4 (where $\sigma_{\varepsilon}$ and $\sigma_{\mathrm{v}}$ are the standard deviation of demand and supply shocks, respectively).

Comparing first the implications of each model for the contemporaneous covariance of output growth with inflation reveals that the P-bar model implies that demand shocks result in a negative covariance, the staggered price setting model implies no contribution of demand shocks to the contemporaneous covariance, and the partial adjustment model implies that demand shocks result in a positive covariance between output growth and inflation. These results are intuitive; in the P-bar model, output growth responds positively at first to an aggregate demand shock, but in the next period inflation rises as output growth falls. In the partial adjustment model, inflation and output growth both respond immediately (and positively) to an aggregate demand shock, resulting in a positive covariance. These results imply

Proposition 1: In order to match the negative correlations between output growth and inflation found in the major North American and European economies, the partial adjustment model requires a larger ratio of the variance of supply shocks to the variance of demand shocks than the staggered price setting model, which in turn requires a larger ratio than the P-bar model.

The covariances reported in table 4 also imply that all three models are capable of matching the phase shift between output growth and inflation reported in table 1 , as $\operatorname{cov}\left(\Delta \mathrm{p}_{\mathrm{t}}, \Delta \mathrm{y}_{\mathrm{t}}\right.$ $\left.{ }_{1}\right)>\operatorname{cov}\left(\Delta \mathrm{p}_{\mathrm{t}}, \Delta \mathrm{y}_{\mathrm{t}+1}\right)$ in all three models. 


\section{Detrended Output and Inflation}

The models presented in section 3 can be used to derive the implication of the different sticky price models for the dynamic behavior of the level of output (table 5). Each model generates similar responses of the level of output to aggregate demand shocks, and passes the non-stationary behavior of aggregate supply (x) to output. Of course, the behavior of inflation is still that given in table 3, and the information imperfections embedded in the staggered price setting model and the P-bar model imply different dynamics for inflation from those of the partial adjustment model.

In order to determine whether the different dynamics imply similar results for the relationship between the deviation of output from a smooth trend and inflation, the effects of the HP-filter must be briefly discussed. Since output inherits a unit root from the unit root in potential output (aggregate supply), the output series must be rendered stationary before computing correlations with inflation. The HP-filter is one method of extracting a smooth trend from an integrated series. As shown in King and Rebelo (1993) and Baxter and King (1999), the HP-filter is equivalent, in large samples, to applying the following two sided moving average to a series;

$$
\mathrm{HP}=\lambda[1-\mathrm{L}]^{2}\left[1-\mathrm{L}^{-1}\right]^{2}\left[1+\lambda[1-\mathrm{L}]^{2}\left[1-\mathrm{L}^{-1}\right]^{2}\right]^{-1},
$$

where $\lambda$ is a smoothing parameter (which for quarterly data is traditionally set at 1600 , so that the HP-filter emphasizes fluctuations with periodicity less than 8 years).

Two properties of the HP-filter are immediately obvious. First, the first differences in the numerator imply that the HP-filter renders stationary a unit root process. Secondly, inspection reveals that the HP-filter is a symmetric filter, i.e. that the coefficient on the kth order lag equals the coefficient on the -kth order lag. This implies that applying the HP-filter to one series does not alter the phase shift (or pattern of lead-lag correlations) between two stationary series (Sargent (1987), King and Rebelo (1993)).

This phase shift preserving property of the HP-filter can be used to examine the implications of the three sticky price models for the relative importance of demand shocks in generating the correlations between HP-filtered output and inflation reported in table 2. As is clear from the above formula for the HP-filter, computing the covariances between inflation and detrended output in terms of the parameters governing price adjustment and the driving processes is tedious, and relatively uninformative. Fortunately, the phase shift between inflation and output can be computed in the frequency domain, which is considerably simpler; (4.1), (4.3), (4.5) and (5.1)-(5.3) express inflation and output in terms of a sequence of innovations, or in the time domain. Alternatively, inflation and output at $\mathrm{t}$ can be expressed as a weighted sum of the periodic functions $\cos (\omega t)$ and $\sin (\omega t)$, where $\omega$ denotes a particular frequency (the frequency domain). The lead-lag relationship between output and inflation is summarized in the frequency domain by the phase statistic $\mathrm{P}^{\mathrm{y}, \Delta \mathrm{p}}(\omega)$, which gives the lead $\left(\mathrm{P}^{\mathrm{y}, \Delta \mathrm{p}}(\omega)>0\right)$ or lag $\left(\mathrm{P}^{\mathrm{y}, \Delta \mathrm{p}}(\omega)<0\right)$ of output (y) over inflation $(\Delta \mathrm{p})$ at frequency $\omega$. Appendix I discusses the phase statistic, which essentially reveals asymmetry in the pattern of cross-correlations between output and inflation, so that the phase shift $\left(\mathrm{P}^{\mathrm{y}, \Delta \mathrm{p}}(\omega)\right)$ is positive when $\rho\left(\Delta \mathrm{p}_{\mathrm{t}}, \mathrm{y}_{\mathrm{t}-\mathrm{i}}\right)>\rho\left(\Delta \mathrm{p}_{\mathrm{t}}, \mathrm{y}_{\mathrm{t}+\mathrm{i}}\right)$, as reported for the economies considered in table 2.

Therefore, focusing on the effects of demand shocks (i.e., when $\sigma_{v}=0$ ), the phase 
statistics implied by the various models summarized in tables 3 and 5 are

$\begin{array}{ll}\text { Partial adjustment: } & \mathrm{P}^{\mathrm{y}, \Delta \mathrm{p}}(\omega)=0 \\ \text { P-Bar: } & \mathrm{P}^{\mathrm{y}, \Delta \mathrm{p}}(\omega)=\arctan (\sin (\omega) / \cos (\omega))=\omega \\ \text { Staggered Price Setting: } & \mathrm{P}^{\mathrm{y}, \Delta \mathrm{p}}(\omega)=\arctan (\sin (\omega) /(1+\cos (\omega))) .\end{array}$

We can transfer from frequencies $\omega$ to cycles of varying periodicity c by the equation $c=2 \pi / \omega$.

Defining the business cycle as cycles of 1 to 8 years, we see that $\omega \in[\pi / 2, \pi / 16]$ for quarterly data. The above formula for the phase shift between $y$ and $\Delta p$ then implies that output leads inflation for the P-Bar and staggered price setting model $\left(\mathrm{P}^{\mathrm{y}, \Delta \mathrm{p}}(\omega)>0\right)$, but not the partial adjustment model. These results lead to proposition 2:

Proposition 2: The partial adjustment model requires supply shocks to match (qualitatively), the leading behavior of output over inflation reported in table 2. The P-bar and staggered price setting model do not.

\section{Discussion and Conclusion}

This paper has documented that inflation and output growth are negatively correlated, inflation and detrended output are positively correlated, and output leads inflation. The comparison of different models of nominal rigidity reveals that the type of price stickiness utilized can strongly alter the conclusions reached regarding the relative importance of supply and demand shocks for the comovement of inflation and output. The partial adjustment model is more reliant on supply shocks in generating the negative correlation between output growth and inflation, and the lead of detrended output over inflation, than other popular sticky price models. This arises because the partial adjustment specification allows all firms to respond immediately to information about monetary shocks, whereas the data suggests the response of inflation is delayed. For example, a traditional explanation for the lead of output over inflation argues that output rises in the presence of excess nominal demand, revealing the excess nominal pressure and resulting in inflation. Without imperfect information, the rise in output does not reveal information about nominal pressure, and hence price stickiness alone does not result in output leading inflation. The P-bar model and staggered price setting both constrain the response of price setters to information about monetary shocks, and can therefore match the lead of output over inflation. The emphasis on imperfect information in explaining the relationship between prices and output has a long history, starting with Hume and continuing in the work of Lucas, Brunner and Meltzer, and Mankiw and Reis.

These results indicate that the recent literature using partial adjustment to model sticky prices in dynamic general equilibrium economies (Hairault and Portier (1993), Kimball (1995), King and Watson (1996), King and Wolman (1996), Rotemberg (1996), Yun (1996), Ireland (1997), Woodford (1998), and Kim (2000)) will match the relationship between nominal and real variables by placing greater emphasis on aggregate supply disturbances than would be placed by alternative models. While the simplicity of the partial adjustment model is attractive, the implications of the partial adjustment model for the comovement between inflation and output are quite different from those of a staggered price setting model (or the P-bar model). Kiley (2002) pursues other peculiarities of the partial adjustment model. 
Table 1: Correlation of Inflation and Output Growth

\begin{tabular}{|c|c|c|c|c|c|}
\hline & U.S. & Canada & $\begin{array}{c}\text { United } \\
\text { Kingdom }\end{array}$ & France & Germany \\
\hline$\rho\left(\Delta \mathrm{p}_{\mathrm{t}}, \Delta \mathrm{y}_{\mathrm{t}-4}\right)$ & $\begin{array}{l}-0.08 \\
(0.10)\end{array}$ & $\begin{array}{c}0.17 \\
(0.12)\end{array}$ & $\begin{array}{l}-0.08 \\
(0.10)\end{array}$ & $\begin{array}{c}0.01 \\
(0.12)\end{array}$ & $\begin{array}{l}0.26^{*} \\
(0.11)\end{array}$ \\
\hline$\rho\left(\Delta \mathrm{p}_{\mathrm{t}}, \Delta \mathrm{y}_{\mathrm{t}-3}\right)$ & $\begin{array}{l}-0.10 \\
(0.11)\end{array}$ & $\begin{array}{c}0.08 \\
(0.10)\end{array}$ & $\begin{array}{l}-0.11 \\
(0.08)\end{array}$ & $\begin{array}{c}0.06 \\
(0.13)\end{array}$ & $\begin{array}{l}0.25^{*} \\
(0.13)\end{array}$ \\
\hline$\rho\left(\Delta \mathrm{p}_{\mathrm{t}}, \Delta \mathrm{y}_{\mathrm{t}-2}\right)$ & $\begin{array}{l}-0.21 \\
(0.11)\end{array}$ & $\begin{array}{c}0.11 \\
(0.10)\end{array}$ & $\begin{array}{l}-0.13 \\
(0.08)\end{array}$ & $\begin{array}{c}0.13 \\
(0.12)\end{array}$ & $\begin{array}{c}0.20 \\
(0.11)\end{array}$ \\
\hline$\rho\left(\Delta \mathrm{p}_{\mathrm{t}}, \Delta \mathrm{y}_{\mathrm{t}-1}\right)$ & $\begin{array}{l}-0.19 * \\
(0.09)\end{array}$ & $\begin{array}{c}0.05 \\
(0.10)\end{array}$ & $\begin{array}{l}-0.14 \\
(0.12)\end{array}$ & $\begin{array}{c}0.07 \\
(0.14)\end{array}$ & $\begin{array}{c}0.07 \\
(0.12)\end{array}$ \\
\hline$\rho\left(\Delta \mathrm{p}_{\mathrm{t}}, \Delta \mathrm{y}_{\mathrm{t}}\right)$ & $\begin{array}{l}-0.26^{*} \\
(0.12)\end{array}$ & $\begin{array}{l}-0.19 \\
(0.11)\end{array}$ & $\begin{array}{c}-0.26 * * \\
(0.09)\end{array}$ & $\begin{array}{c}0.00 \\
(0.14)\end{array}$ & $\begin{array}{l}-0.05 \\
(0.14)\end{array}$ \\
\hline$\rho\left(\Delta \mathrm{p}_{\mathrm{t}}, \Delta \mathrm{y}_{\mathrm{t}+1}\right)$ & $\begin{array}{c}-0.32 * * \\
(0.09)\end{array}$ & $\begin{array}{l}-0.03 \\
(0.10)\end{array}$ & $\begin{array}{c}-0.23 * * \\
(0.08)\end{array}$ & $\begin{array}{c}0.01 \\
(0.14)\end{array}$ & $\begin{array}{l}-0.12 \\
(0.12)\end{array}$ \\
\hline$\rho\left(\Delta \mathrm{p}_{\mathrm{t}}, \Delta \mathrm{y}_{\mathrm{t}+2}\right)$ & $\begin{array}{c}-0.33^{* *} \\
(0.09)\end{array}$ & $\begin{array}{l}-0.08 \\
(0.10)\end{array}$ & $\begin{array}{l}-0.17 \\
(0.09)\end{array}$ & $\begin{array}{l}-0.13 \\
(0.17)\end{array}$ & $\begin{array}{l}-0.23 \\
(0.14)\end{array}$ \\
\hline$\rho\left(\Delta \mathrm{p}_{\mathrm{t}}, \Delta \mathrm{y}_{\mathrm{t}+3}\right)$ & $\begin{array}{c}-0.30 * * \\
(0.10)\end{array}$ & $\begin{array}{l}-0.14 \\
(0.11)\end{array}$ & $\begin{array}{l}-0.17 \\
(0.12)\end{array}$ & $\begin{array}{l}-0.01 \\
(0.13)\end{array}$ & $\begin{array}{l}-0.11 \\
(0.11)\end{array}$ \\
\hline$\rho\left(\Delta \mathrm{p}_{\mathrm{t}}, \Delta \mathrm{y}_{\mathrm{t}+4}\right)$ & $\begin{array}{l}-0.24 \\
(0.13)\end{array}$ & $\begin{array}{l}-0.18 \\
(0.11)\end{array}$ & $\begin{array}{l}-0.19 * \\
(0.08)\end{array}$ & $\begin{array}{c}0.03 \\
(0.12)\end{array}$ & $\begin{array}{l}--0.12 \\
(0.10)\end{array}$ \\
\hline
\end{tabular}

Correlations reflect author's calculations based on OECD Main Economic Indicators-CDROM data.

Standard errors in parentheses are robust to heteroskedasticity and autocorrelation (Newey-West) with bandwidth parameter set at $\mathrm{N}^{1 / 3}$.

Sample periods reflect maximum period available: U.S. (61:2-93:4), Canada (61:2-93:4), United Kingdom (61:293:4), France (71:2-93:4), and Germany (69:2-93:4).

* significant at the 5\% level.

** significant at the $1 \%$ level. 
Table 2: Correlation of Inflation and HP-filtered Output

\begin{tabular}{|c|c|c|c|c|c|}
\hline & U.S. & Canada & $\begin{array}{c}\text { United } \\
\text { Kingdom }\end{array}$ & France & Germany \\
\hline$\rho\left(\Delta \mathrm{p}_{\mathrm{t}}, \mathrm{y}_{\mathrm{t}-4}\right)$ & $\begin{array}{l}0.29 * \\
(0.14)\end{array}$ & $\begin{array}{l}0.25^{*} \\
(0.11)\end{array}$ & $\begin{array}{l}0.31 * \\
(0.13)\end{array}$ & $\begin{array}{c}0.08 \\
(0.20)\end{array}$ & $\begin{array}{l}0.28 * \\
(0.11)\end{array}$ \\
\hline$\rho\left(\Delta \mathrm{p}_{\mathrm{t}}, \mathrm{y}_{\mathrm{t}-3}\right)$ & $\begin{array}{l}0.31 * \\
(0.13)\end{array}$ & $\begin{array}{c}0.30 * * \\
(0.10)\end{array}$ & $\begin{array}{l}0.29 * \\
(0.13)\end{array}$ & $\begin{array}{c}0.08 \\
(0.20)\end{array}$ & $\begin{array}{c}0.35 * * \\
(0.09)\end{array}$ \\
\hline$\rho\left(\Delta \mathrm{p}_{\mathrm{t}}, \mathrm{y}_{\mathrm{t}-2}\right)$ & $\begin{array}{l}0.28 * \\
(0.13)\end{array}$ & $\begin{array}{c}0.36 * * \\
(0.10)\end{array}$ & $\begin{array}{l}0.24 * \\
(0.12)\end{array}$ & $\begin{array}{c}0.12 \\
(0.20)\end{array}$ & $\begin{array}{c}0.40 * * \\
(0.07)\end{array}$ \\
\hline$\rho\left(\Delta \mathrm{p}_{\mathrm{t}}, \mathrm{y}_{\mathrm{t}-1}\right)$ & $\begin{array}{l}0.26^{*} \\
(0.13)\end{array}$ & $\begin{array}{c}0.38 * * \\
(0.10)\end{array}$ & $\begin{array}{c}0.20 \\
(0.16)\end{array}$ & $\begin{array}{c}0.13 \\
(0.19)\end{array}$ & $\begin{array}{c}0.39 * * \\
(0.08)\end{array}$ \\
\hline$\rho\left(\Delta \mathrm{p}_{\mathrm{t}}, \mathrm{y}_{\mathrm{t}}\right)$ & $\begin{array}{c}0.20 \\
(0.15)\end{array}$ & $\begin{array}{l}0.26^{*} \\
(0.11)\end{array}$ & $\begin{array}{c}0.08 \\
(0.14)\end{array}$ & $\begin{array}{c}0.10 \\
(0.19)\end{array}$ & $\begin{array}{c}0.33 * * \\
(0.10)\end{array}$ \\
\hline$\rho\left(\Delta \mathrm{p}_{\mathrm{t}}, \mathrm{y}_{\mathrm{t}+1}\right)$ & $\begin{array}{c}0.10 \\
(0.16)\end{array}$ & $\begin{array}{l}0.24 * \\
(0.12)\end{array}$ & $\begin{array}{l}-0.02 \\
(0.15)\end{array}$ & $\begin{array}{c}0.08 \\
(0.19)\end{array}$ & $\begin{array}{c}0.23 \\
(0.13)\end{array}$ \\
\hline$\rho\left(\Delta \mathrm{p}_{\mathrm{t}}, \mathrm{y}_{\mathrm{t}+2}\right)$ & $\begin{array}{l}-0.01 \\
(0.17)\end{array}$ & $\begin{array}{c}0.19 \\
(0.12)\end{array}$ & $\begin{array}{l}-0.08 \\
(0.15)\end{array}$ & $\begin{array}{c}-0.03 \\
(0.19)\end{array}$ & $\begin{array}{c}0.09 \\
(0.16)\end{array}$ \\
\hline$\rho\left(\Delta \mathrm{p}_{\mathrm{t}}, \mathrm{y}_{\mathrm{t}+3}\right)$ & $\begin{array}{l}-0.10 \\
(0.17)\end{array}$ & $\begin{array}{c}0.11 \\
(0.13)\end{array}$ & $\begin{array}{l}-0.12 \\
(0.13)\end{array}$ & $\begin{array}{c}-0.07 \\
(0.19)\end{array}$ & $\begin{array}{c}0.02 \\
(0.18)\end{array}$ \\
\hline$\rho\left(\Delta \mathrm{p}_{\mathrm{t}}, \mathrm{y}_{\mathrm{t}+4}\right)$ & $\begin{array}{l}-0.16 \\
(0.16)\end{array}$ & $\begin{array}{l}-0.00 \\
(0.14)\end{array}$ & $\begin{array}{l}-0.19 \\
(0.13)\end{array}$ & $\begin{array}{l}-0.09 \\
(0.19)\end{array}$ & $\begin{array}{l}--0.06 \\
(0.17)\end{array}$ \\
\hline
\end{tabular}

Correlations reflect author's calculations based on OECD Main Economic Indicators-CDROM data.

Standard errors in parentheses are robust to heteroskedasticity and autocorrelation (Newey-West) with bandwidth parameter set at $\mathrm{N}^{1 / 3}$.

The smoothing parameter for the HP-filter was set at 1600 .

Sample periods reflect maximum period available: U.S. (61:1-93:4), Canada (61:1-93:4), United Kingdom (61:193:4), France (71:1-93:4), and Germany (69:1-93:4).

* significant at the $5 \%$ level.

** significant at the $1 \%$ level. 


\begin{tabular}{|l|}
\hline \multicolumn{1}{|c|}{ Partial Adjustment Model } \\
$\Delta \mathrm{p}_{\mathrm{t}}=\pi[1-(1-\pi) \mathrm{L}]^{-1}\left[\varepsilon_{\mathrm{t}}-\mathrm{v}_{\mathrm{t}}\right]$ \\
$\Delta \mathrm{y}_{\mathrm{t}}=(1-\pi)[1-(1-\pi) \mathrm{L}]^{-1}[1-\mathrm{L}] \varepsilon_{\mathrm{t}}-\pi[1-(1-\pi) \mathrm{L}]^{-1} \mathrm{v}_{\mathrm{t}}$ \\
\hline \multicolumn{1}{|c|}{ P-Bar Model } \\
$\Delta \mathrm{p}_{\mathrm{t}}=\pi[1-(1-\pi) \mathrm{L}]^{-1}[\mathrm{~L}]\left[\varepsilon_{\mathrm{t}}-\mathrm{v}_{\mathrm{t}}\right]$ \\
$\Delta \mathrm{y}_{\mathrm{t}}=[1-(1-\pi) \mathrm{L}]^{-1}[1-\mathrm{L}] \varepsilon_{\mathrm{t}}-\pi[1-(1-\pi) \mathrm{L}]^{-1} \mathrm{Lv} \mathrm{v}_{\mathrm{t}}$ \\
\hline$\quad$ Staggered Price Setting Model \\
\hline$\Delta \mathrm{p}_{\mathrm{t}}=(\pi / 2)[1-(1-\pi) \mathrm{L}]^{-1}[1+\mathrm{L}\}\left[\varepsilon_{\mathrm{t}}-\mathrm{v}_{\mathrm{t}}\right]$ \\
$\Delta \mathrm{y}_{\mathrm{t}}=((2-\pi) / 2)[1-(1-\pi) \mathrm{L}]^{-1}[1-\mathrm{L}] \varepsilon_{\mathrm{t}}-(\pi / 2)[1-(1-\pi) \mathrm{L}]^{-1}[1+\mathrm{L}] \mathrm{v}_{\mathrm{t}}$ \\
\hline
\end{tabular}


Table 4: Covariances of Inflation and Output Growth

\begin{tabular}{|cccc|}
\hline & $\operatorname{cov}\left(\Delta \mathrm{p}_{\mathrm{t}}, \mathrm{y}_{\mathrm{t}-1}\right)$ & $\operatorname{cov}\left(\Delta \mathrm{p}_{\mathrm{t}}, \mathrm{y}_{\mathrm{t}}\right)$ & $\operatorname{cov}\left(\Delta \mathrm{p}_{\mathrm{t}}, \mathrm{y}_{\mathrm{t}+1}\right)$ \\
Partial & $\pi^{2}\left[1-(1-\pi)^{2}\right]^{-1}$ & $-\pi^{2}\left[1-(1-\pi)^{2}\right]^{-1}\left[(\pi-1) \sigma_{\varepsilon}{ }^{2}+\sigma_{\mathrm{v}}{ }^{2}\right]$ & $-\pi^{2}\left[1-(1-\pi)^{2}\right]^{-1}$ \\
Adjustment & $(1-\pi)\left[(1-\pi) \sigma_{\varepsilon}{ }^{2}-\sigma_{\mathrm{v}}{ }^{2}\right]$ & & $(1-\pi)\left[\sigma_{\varepsilon}{ }^{2}+\sigma_{\mathrm{v}}{ }^{2}\right]$ \\
& & & \\
P-Bar & $\pi^{2}\left[1-(1-\pi)^{2}\right]^{-1}\left[\sigma_{\varepsilon}{ }^{2}-(1-\pi) \sigma_{\mathrm{v}}{ }^{2}\right]$ & $-\pi^{2}\left[1-(1-\pi)^{2}\right]^{-1}\left[\sigma_{\varepsilon}{ }^{2}+\sigma_{\mathrm{v}}{ }^{2}\right]$ & $-\pi^{2}\left[1-(1-\pi)^{2}\right]^{-1}$ \\
& & & $(1-\pi)\left[\sigma_{\varepsilon}{ }^{2}+\sigma_{\mathrm{v}}{ }^{2}\right]$ \\
Staggered & {$\left[1-(1-\pi)^{2}\right]^{-1}$} & $-\pi^{2}(1-\pi / 2)\left[1-(1-\pi)^{2}\right]^{-1} \sigma_{\mathrm{v}}{ }^{2}$ & $-\left[1-(1-\pi)^{2}\right]^{-1}$ \\
Price & {$\left[(\pi(2-\pi) / 4)\left(1-(1-\pi)^{2}\right) \sigma_{\varepsilon}{ }^{2}\right.$} & & {$\left[(\pi(2-\pi) / 4)\left(1-(1-\pi)^{2}\right) \sigma_{\varepsilon}{ }^{2}\right.$} \\
Setting & $-\left(\pi^{2} / 4\right)\left(2(1-\pi)+1+(1-\pi)^{2} \sigma_{\mathrm{v}}{ }^{2}\right]$ & & $+\left(\pi^{2} / 4\right)\left(2(1-\pi)+1+(1-\pi)^{2} \sigma_{\mathrm{v}}{ }^{2}\right]$ \\
\hline
\end{tabular}

Table 5: Output Processes

\begin{tabular}{|c|}
\hline \multicolumn{1}{|c|}{ Partial Adjustment Model } \\
$\mathrm{y}_{\mathrm{t}}=(1-\pi)[1-(1-\pi) \mathrm{L}]^{-1} \varepsilon_{\mathrm{t}}-\pi[1-(1-\pi) \mathrm{L}]^{-1} \mathrm{x}_{\mathrm{t}}$ \\
\hline \multicolumn{1}{c}{ P-Bar Model } \\
$\mathrm{y}_{\mathrm{t}}=[1-(1-\pi) \mathrm{L}]^{-1} \varepsilon_{\mathrm{t}}-\pi[1-(1-\pi) \mathrm{L}]^{-1} \mathrm{Lx}_{\mathrm{t}}$ \\
\hline Staggered Price Setting Model \\
$\mathrm{y}_{\mathrm{t}}=((2-\pi) / 2)[1-(1-\pi) \mathrm{L}]^{-1} \varepsilon_{\mathrm{t}}-(\pi / 2)[1-(1-\pi) \mathrm{L}]^{-1}[1+\mathrm{L}] \mathrm{x}_{\mathrm{t}}$
\end{tabular}




\section{Appendix I: \\ The Phase Shift Between Output and Inflation}

An introduction to frequency domain analysis with macroeconomic applications is Sargent (1987). All of the models considered in section 5 express output and inflation as polynomial functions in the lag operator of the shock to money or nominal aggregate demand. Denoting these functions as $c_{y} B_{y}(L)$ and $c_{\Delta P} B_{\Delta P}(L)$, the cross covariance generating of $y$ and $\Delta P$, $\mathrm{g}_{\mathrm{y}, \Delta \mathrm{P}}(\mathrm{z})$, is

$$
\mathrm{g}_{\mathrm{y}, \Delta \mathrm{P}}(\mathrm{z})=\mathrm{c}_{\mathrm{y}} \mathrm{c}_{\Delta \mathrm{P}} \sigma_{\varepsilon} \mathrm{B}_{\mathrm{y}}(\mathrm{z}) \mathrm{B}_{\Delta \mathrm{P}}\left(\mathrm{z}^{-1}\right) \text {. }
$$

This cross covariance generating function is a simple way to summarize the pattern of cross correlations between output and inflation.

A straightforward method for evaluating whether output leads inflation, i.e. whether inflation is more strongly correlated with lagged output than future output, is to look at the asymmetry in the cross covariance generating function. A measure of this asymmetry is the phase statistic in frequency domain analysis, which requires the cross spectrum.

The cross spectrum is found by evaluating the cross covariance generating function at $\mathrm{z}=\mathrm{e}^{-\mathrm{i} \omega}$, where $\mathrm{i}=(-1)^{1 / 2}$, and $\omega$ refers to the frequency, $\omega \in[-\pi . \pi]$. The phase statistic is found by taking the cross spectrum $\left(\mathrm{g}_{\mathrm{y}, \Delta \mathrm{P}}\left(\mathrm{e}^{-\mathrm{i} \omega}\right)\right)$ and expressing it in terms of its real and imaginary parts, $\mathrm{g}_{\mathrm{y}, \Delta \mathrm{P}}\left(\mathrm{e}^{-\mathrm{i} \omega}\right)=\operatorname{co}(\omega)+\mathrm{iqu}(\omega)$,

where the real part (co) is called the cospectrum and the imaginary part (qu) is called the quadrature spectrum. The phase statistic between $\mathrm{y}$ and $\Delta \mathrm{P}$ is then

$$
\mathrm{P}^{\mathrm{y}, \Delta \mathrm{P}}(\omega)=\arctan (\mathrm{qu}(\omega) / \operatorname{co}(\omega)) \text {. }
$$

Application of this technique to the various models yields the phase statistics given in the text. Output leads inflation at frequency $\omega$ if $\mathrm{P}^{\mathrm{y}, \Delta \mathrm{p}}(\omega)>0$, and output lags inflation at frequency $\omega$ if $\mathrm{P}^{\mathrm{y}, \Delta \mathrm{p}}(\omega)<0$. 


\section{References}

Ball, L., Mankiw, N.G., and Romer D. (1988) The New Keynesian Economics and the Output Inflation Tradeoff. Brookings Papers on Economic Activity 1:1-65.

Barro, R.J. and Grossman, H.I. (1976) Money, Employment, and Inflation. Cambridge University Press.

Baxter, M. and King, R.G. (1999) Measuring Business Cycles: Approximate Band-Pass Filters for Economic Time Series. Review of Economics and Statistics 81:575-93.

Blanchard, O.J., and Fischer, S. (1989) Lectures on Macroeconomics. MIT Press.

Brunner, K and Meltzer, A.H. (1993) Money and the Economy: Issues in Monetary Analysis. Cambridge University Press.

Calvo, G.A. (1983) Staggered Prices in a Utility Maximizing Framework. Journal of Monetary Economics 12:383-398.

Chadha, B. and Prasad, E. (1993) Interpreting the Cyclical Behavior of Prices. International Monetary Fund Staff Papers 40:266-98.

Chadha, B. and Prasad, E. (1994) Are Prices Countercyclical? Evidence from the G-7. Journal of Monetary Economics 34:239-57.

Cooley, T.F. and Hansen, G.D. (1995) Money and the Business Cycle. In Cooley, T.F., ed. Frontiers of Business Cycle Research. Princeton University Press. 175-216.

Cooley, T.F. and Ohanian, L.E. (1991) The Cyclical Behavior of Prices. Journal of Monetary Economics 28:25-60.

den Haan, W. (2000) The Comovement between Output and Prices. Journal of Monetary Economics 46:3-30.

Flood, R.P. and Hodrick, R.G. (1985) Optimal Price and Inventory Adjustment in an Open Economy Model of the Business Cycle. Quarterly Journal of Economics 100:887-914.

Grossman, H.I. (1974) The Cyclical Pattern of Unemployment and Wage Inflation. Economica 41:403-13.

Hairault, J.O. and Portier, F. (1993) Money, New Keynesian Macroeconomics and the Business Cycle. European Economic Review 37:1533-68.

Hume, D. (1752) Of Money. As reproduced in Rotwein, E. (1955) David Hume: Writings on Economics. University of Wisconsin Press. 33-46.

Ireland, P.N. (1997) A Small, Structural, Quarterly Model for Monetary Policy Evaluation. Carnegie Rochester Conference Series on Public Policy 47:83-108.

Judd, J.P. and Trehan, B. (1995) The Cyclical Behavior of Prices: Interpreting and Evidence. Journal of Money, Credit, and Banking 27:789-97.

Kiley, M.T. (2000) Price Stickiness and Business Cycle Persistence. Journal of Money, Credit, and Banking 32:28-53.

Kiley, M.T. (2002) Partial Adjustment and Staggered Price Setting. Journal of Money, Credit, and Banking 34:283-298.

Kim, J. (2000) Constructing and Estimating a Realistic Optimizing Model of Monetary Policy. Journal of Monetary Economics 45:329-59.

Kimball, M. (1995) The Quantitative Analytics of the Basic Neomonetarist Model. Journal of Money, Credit, and Banking 27:1241-1277.

King, R.G. and Rebelo, S.T. (1993) Low Frequency Filtering and Real Business Cycles. Journal 
of Economic Dynamics and Control 17:207-231.

King, R.G. and Watson, M. (1996) Money, Output, Prices, and Interest Rates. Review of Economics and Statistics 78:35-53.

King, R.G. and Wolman, A. (1996) Inflation Targeting in a St. Louis Model of the 21 st Century. Federal Reserve Bank of St. Louis Review 78:83-107.

Lucas, R.E. Jr. (1973) Some International Evidence on Output Inflation Tradeoffs. American Economic Review 63:326-34.

Lucas, R.E. Jr. (1977) Understanding Business Cycles. In Brunner, K. and Meltzer, A., eds. Stabilization of the Domestic and International Economy. North Holland. 7-29.

Lucas, R.E. Jr. (1987) Models of Business Cycles. Basil Blackwell, Inc.

Mankiw, N.G., and Reis, R. (2001) Sticky Information: A Model of Monetary Nonneutrality and Structural Slumps. NBER Working Paper No. 8614, December.

McCallum, B.T. (1979) A Monetary Policy Ineffectiveness Result in a Model with a Predetermined Price Level. Economics Letters 3:1-4.

McCallum, B.T. (1994) A Semi-Classical Model of Price Level Adjustment. Carnegie-Rochester Conference Series on Public Policy 41:251-84.

Mussa, M. (1981a) Sticky Individual Prices and the Dynamics of the General Price Level. Carnegie-Rochester Conference Series on Public Policy 15:261-96.

Mussa, M. (1981b) Sticky Prices and Disequilibrium Adjustment in a Rational Model of the Inflationary Process. American Economic Review 71:1020-1027.

Mussa, M. (1982) A Model of Exchange Rate Dynamics. Journal of Political Economy 90:79104.

Obstfeld, M. and Rogoff, K. (1984) Exchange Rate Dynamics with Sluggish Prices under Alternative Price Adjustment Rules. International Economic Review 25:159-74.

Rotemberg, J.J. (1982) Sticky Prices in the United States. Journal of Political Economy 90:1187211.

Rotemberg, J.J. (1987) The New Keynesian Microfoundations. NBER Macroeconomics Annual 1987. 69-104.

Rotemberg, J.J. (1996) Prices, Output, and Hours: An Empirical Analysis Based on a Sticky Price Model. Journal of Monetary Economics 37:505-33.

Sargent, T. (1987) Macroeconomic Theory. Academic Press.

Taylor, J.B. (1980) Aggregate Dynamics and Staggered Contracts. Journal of Political Economy. 88:1-23.

Taylor, J.B. (1987) Externalities Associated with Nominal Price and Wage Rigidities. In Barnett, W.A. and Singleton, K.J., eds. New Approaches to Monetary Economics. Cambridge University Press. 350-367.

Yun, T. (1996) Nominal Price Rigidity, Money Supply Endogeneity, and Business Cycles. Journal-of-Monetary-Economics 37:345-70.

Woodford, M. (1998) Control of the Public Debt: A Requirement for Price Stability? In G. Calvo and M. King eds. The Debt Burden and Its Consequences for Monetary Policy. International Economic Association Conference Volume, no. 118. St. Martin's Press. 117-54. 